\title{
Bias Stress Stability of Solution-Processed Nano Indium Oxide Thin Film Transistor
}

\author{
Rihui Yao ${ }^{1}{ }^{\circledR}$, Xiao Fu ${ }^{1}$, Wanwan $\mathrm{Li}^{1}$, Shangxiong Zhou ${ }^{1}$, Honglong Ning ${ }^{1, * \mathbb{C}}$, Biao Tang ${ }^{2}$, Jinglin Wei ${ }^{1}$, \\ Xiuhua Cao ${ }^{3, *}$, Wei $\mathrm{Xu}^{1}$ and Junbiao Peng ${ }^{1}$
}

1 State Key Laboratory of Luminescent Materials and Devices, Institute of Polymer Optoelectronic Materials and Devices, South China University of Technology, Guangzhou 510640, China; yaorihui@scut.edu.cn (R.Y.); 201630343721@mail.scut.edu.cn (X.F.); mswanwanli@mail.scut.edu.cn (W.L.); 201820117973@mail.scut.edu.cn (S.Z.); magicwei@foxmail.com (J.W.); xuwei@scut.edu.cn (W.X.); psjbpeng@scut.edu.cn (J.P.)

2 Guangdong Provincial Key Laboratory of Optical Information Materials and Technology \& Institute of Electronic Paper Displays, South China Academy of Advanced Optoelectronics, South China Normal University, Guangzhou 510006, China; biao.tang@guohua-oet.com

3 State Key Laboratory of Advanced Materials and Electronic Components, Fenghua Electronic Industrial Park, No. 18 Fenghua Road, Zhaoqing 526020, China

* Correspondence: ninghl@scut.edu.cn (H.N.); xiuhuacao@126.com (X.C.); Tel.: +86-20-8711-4525 (H.N.)

Citation: Yao, R.; Fu, X.; Li, W.; Zhou, S.; Ning, H.; Tang, B.; Wei, J.; Cao, X.; $\mathrm{Xu}, \mathrm{W}$; Peng, J. Bias Stress Stability of Solution-Processed Nano Indium Oxide Thin Film Transistor. Micromachines 2021, 12, 111. https://doi.org/10.3390/mi12020111

Academic Editor: Giovanni Verzellesi Received: 28 December 2020

Accepted: 19 January 2021

Published: 22 January 2021

Publisher's Note: MDPI stays neutral with regard to jurisdictional claims in published maps and institutional affiliations.

Copyright: (C) 2021 by the authors Licensee MDPI, Basel, Switzerland. This article is an open access article distributed under the terms and conditions of the Creative Commons Attribution (CC BY) license (https:// creativecommons.org/licenses/by/ $4.0 /)$.

\begin{abstract}
In this paper, the effects of annealing temperature and other process parameters on spincoated indium oxide thin film transistors $\left(\mathrm{In}_{2} \mathrm{O}_{3}\right.$-TFTs) were studied. The research shows that plasma pretreatment of glass substrate can improve the hydrophilicity of glass substrate and stability of the spin-coating process. With Fourier transform infrared (FT-IR) and X-ray diffraction (XRD) analysis, it is found that $\operatorname{In}_{2} \mathrm{O}_{3}$ thin films prepared by the spin coating method are amorphous, and have little organic residue when the annealing temperature ranges from 200 to $300^{\circ} \mathrm{C}$. After optimizing process conditions with the spin-coated rotating speed of $4000 \mathrm{rpm}$ and the annealing temperature of $275{ }^{\circ} \mathrm{C}$, the performance of $\mathrm{In}_{2} \mathrm{O}_{3}$-TFTs is best (average mobility of $1.288 \mathrm{~cm}^{2} \cdot \mathrm{V}^{-1} \cdot \mathrm{s}^{-1}, \mathrm{I}_{\text {on }} / \mathrm{I}_{\text {off }}$ of $5.93 \times 10^{6}$, and SS of $0.84 \mathrm{~V} \cdot \mathrm{dec}^{-1}$ ). Finally, the stability of $\mathrm{In}_{2} \mathrm{O}_{3}$-TFTs prepared at different annealing temperatures was analyzed by energy band theory, and we identified that the elimination of residual hydroxyl groups was the key influencing factor. Our results provide a useful reference for high-performance metal oxide semiconductor TFTs prepared by the solution method.
\end{abstract}

Keywords: indium oxide thin film; solution method; plasma surface treatment; annealing temperature; bias stability

\section{Introduction}

With the active matrix liquid crystal display (AMLCD) and active matrix organic light-emitting diodes (AMOLED) gradually occupying the mainstream position in the display field [1-4], metal oxide thin film transistors (MOS-TFTs) have been widely studied due to their high mobility, high light transmittance, low processing temperature and low processing cost [3-9]. At present, metal oxide semiconductors are mainly fabricated by vacuum deposition methods, which have strict environmental requirements and relatively high manufacturing cost $[10,11]$. In contrast, solution-processed deposition offers the advantages of a simple process, high-throughput, high material utilization rate, and easy control of chemical components, which provides the possibility for large-area preparation of metal oxide semiconductor [12-17]. The preparation of metal oxides by the solution method usually requires annealing, which promotes the formation of $(\mathrm{M}-\mathrm{O}-\mathrm{M})$ structure and the densification of film [18]. Solution methods mainly include the spin-coating method, solvothermal method, microwave assisted growth method, sonochemical method, hydrothermal method, electrodeposition method and so on [19-25]. Among them, the spin-coating method has the advantages of low cost, low pollution, energy saving and low 
film thickness, but it also has the disadvantages of uneven film thickness and waste of solution.

Nowadays, metal oxide semiconductor materials with $(n-1) \mathrm{d}^{10} \mathrm{~ns}^{0}(n \geq 4)$ electronic configurations have attracted much attention due to their good electrical properties in the amorphous phase, and indium oxide $\left(\operatorname{In}_{2} \mathrm{O}_{3}\right)$ is one of them [26,27]. This meets the requirements of low temperature preparation in the field of flexible display. $\operatorname{In}_{2} \mathrm{O}_{3}$ has been widely studied in the preparation of TFT active layer due to its wide band gap, high mobility, high carrier concentration and good transparency [1,28-31], but there is still little research on the influence mechanism of amorphous $\operatorname{In}_{2} \mathrm{O}_{3}$ electrical stability [32].

In this paper, $\mathrm{In}_{2} \mathrm{O}_{3}$ thin films were prepared by spin coating. The spreading property of precursor solution was improved by plasma surface treatment [33]. The phase composition of $\mathrm{In}_{2} \mathrm{O}_{3}$ thin films was investigated by different annealing methods. On this basis, $\mathrm{In}_{2} \mathrm{O}_{3}$-TFTs were fabricated on $\mathrm{Al}$ electrodes and $\mathrm{Si}_{3} \mathrm{~N}_{4}$ substrates and the electrical characteristics of devices under different process conditions were analyzed. Furthermore, the possible methods to further improve the performance of TFTs prepared by spin coating were explored.

\section{Materials and Methods}

A semiconductor precursor solution was prepared using Indium nitrate hydrate $\left(\mathrm{In}\left(\mathrm{NO}_{3}\right)_{3} \cdot 5 \mathrm{H}_{2} \mathrm{O}\right.$, CAS No.: 13465-14-0), in a solvent of ethylene glycol monomethyl ether (2-MOE, CAS No.: 109-86-4). The precursor solution was stirred in a magnetic mixer for $30 \mathrm{~min}$ and filtered, and then ultrasonic treatment was performed for $10 \mathrm{~min}$. After plasma surface treatment, $35 \mu \mathrm{L}$ of $\operatorname{In}_{2} \mathrm{O}_{3}$ precursor solution was added dropwise to the single-crystal silicon (CAS No.: 7440-21-3), and then spin coated with a homogenizer (model: KW-4A) at the speed of $4000 \mathrm{rms}$ for $30 \mathrm{~s}$. In the multilayer spin-coating process, every single-layer was pre-annealed at $100^{\circ} \mathrm{C}$ for $10 \mathrm{~min}$ to evaporate the solvent. Finally, the $\mathrm{In}_{2} \mathrm{O}_{3}$ films were annealed at $200{ }^{\circ} \mathrm{C}, 225{ }^{\circ} \mathrm{C}, 250{ }^{\circ} \mathrm{C}, 275{ }^{\circ} \mathrm{C}$ and $300{ }^{\circ} \mathrm{C}$ for $45 \mathrm{~min}$ respectively. For the fabrication of $\mathrm{In}_{2} \mathrm{O}_{3}$-TFTs, bottom-gate devices were fabricated on $\mathrm{Al}$ (CAS No.: 7429-90-5) gate electrode and $\mathrm{Si}_{3} \mathrm{~N}_{4}$ (CAS No.: 27198-71-6) dielectric layer. After the deposition of $\mathrm{In}_{2} \mathrm{O}_{3}$ thin films, an $\mathrm{Al}$ source and drain electrodes were formed by magnetron sputtering through a shadow mask. The schematic structure of the $\operatorname{In}_{2} \mathrm{O}_{3}$-TFTs is shown in Figure 1.

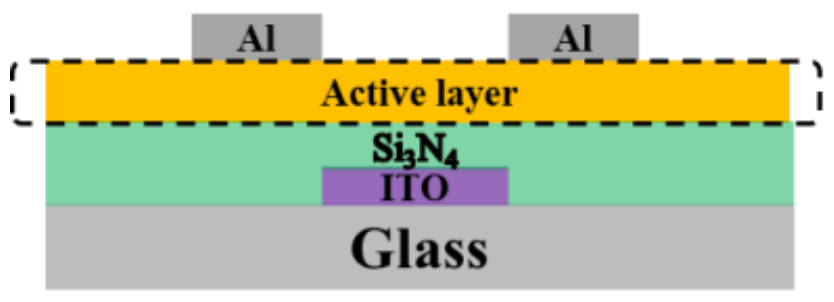

Figure 1. Schematic of indium oxide thin film transistors $\left(\mathrm{In}_{2} \mathrm{O}_{3}\right.$-TFTs).

The surface tension of $\mathrm{In}_{2} \mathrm{O}_{3}$ solutions were measured by an Attension Theta Lite (TL200, Biolin Scientific, Gothenburg, Sweden). The internal chemical composition of $\operatorname{In}_{2} \mathrm{O}_{3}$ thin films was observed by Fourier transform infrared spectroscopy (FT-IR) (IRprestige21, Shimadzu, Kyoto, Janpan). X-ray reflectivity (XRR) (EMPYREAN, PANalytical, Almelo, The Netherlands) was used to analyze the thickness of the films. X-ray diffraction (XRD) (EMPYREAN, PANalytical, Almelo, The Netherlands) was used to analyze the phase of the films with $\mathrm{Cu}-\mathrm{k} \alpha$ as the X-ray source, and the scanning speed is $0.1^{\circ} \cdot \mathrm{s}^{-1}$ from $20^{\circ}$ to $70^{\circ}$. The surface morphology of the films was measured by atomic force microscopy (AFM) (Being Nano-Instruments BY3000, Being Nano-Instruments, Beijing, China). Semiconductor parameter analyzers (Agilent 4155c, Agilent, Santa Clara, CA, USA) was used under an ambient atmosphere to evaluate the electrical characteristics of TFTs. 


\section{Results and Discussion}

\subsection{Effect of Plasma Surface Treatment on Solution Spreading}

Figure 2a,b show the spread situation of $\operatorname{In}_{2} \mathrm{O}_{3}$ precursor solutions without/with plasma surface treatment. It can be found that it is difficult for the $\operatorname{In}_{2} \mathrm{O}_{3}$ precursor solution to spread uniformly on the substrate without plasma treatment. They agglomerate into many small droplets on the substrate, so the uniformity of the film is poor. However, on the substrate treated by plasma, the precursor solution of $\operatorname{In}_{2} \mathrm{O}_{3}$ can be spread uniformly without agglomeration, which indicates that plasma surface treatment can significantly improve the film-forming ability of spin coating. The results characterized by Attension Theta Lite show that the surface tension of $\operatorname{In}\left(\mathrm{NO}_{3}\right)_{3}$ solution is $39 \mathrm{mN} \cdot \mathrm{m}^{-1}$, while that of 2-MOE is $27.6 \mathrm{mN} \cdot \mathrm{m}^{-1}$, this difference easily leads to the spontaneous agglomeration of micro droplets after spin coating, so the film-forming ability is poor; however, plasma treatment can effectively reduce the difference of surface tension by introducing polarization groups into the surface of the substrate, thus improving the hydrophilicity of the substrate surface, which can improve the uniformity of spin-coating films [34-36]. Based on this result, the subsequent films and TFTs are prepared on substrates with plasma surface treatment.

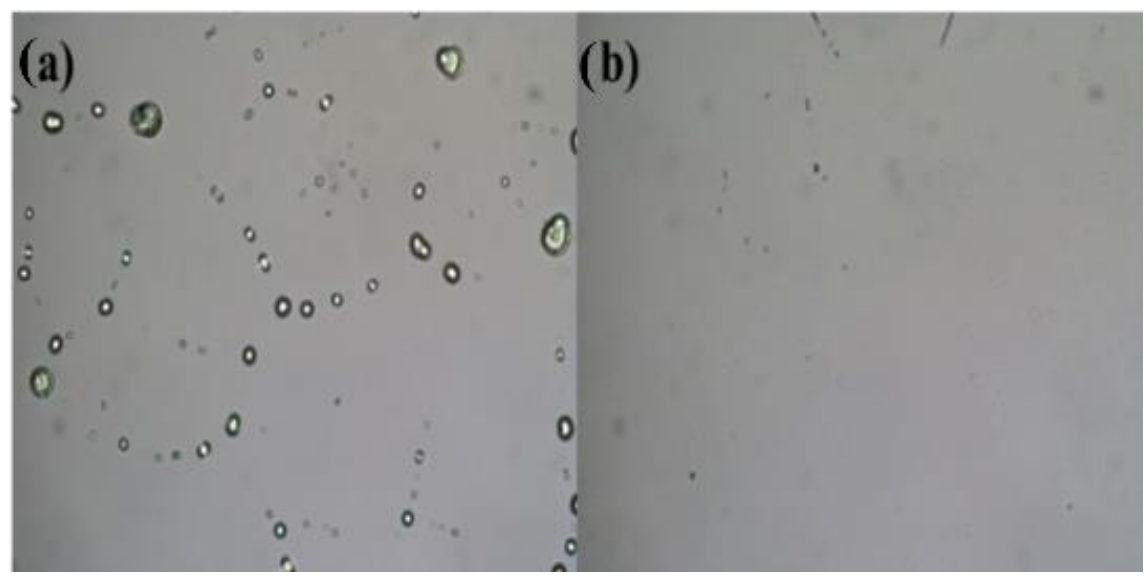

Figure 2. Spreading situation of precursor solution: (a) without plasma surface treatment; (b) with plasma surface treatment.

\subsection{Effect of Annealing Temperature on $\mathrm{In}_{2} \mathrm{O}_{3}$ Thin Films and TFTs}

Figure 3 shows the FT-IR test curves of $\operatorname{In}_{2} \mathrm{O}_{3}$ thin films prepared at different annealing temperatures. The absorption peak located at $2750 \mathrm{~cm}^{-1}$ to $3750 \mathrm{~cm}^{-1}$ is the stretching vibration of $\mathrm{O}-\mathrm{H}$ bond [37], The absorption peak at $1250 \mathrm{~cm}^{-1}$ to $1750 \mathrm{~cm}^{-1}$ were caused by the bending vibration of the carbon-hydrogen bond and carbon-oxygen bond [38]. The absorption peak at $500-700 \mathrm{~cm}^{-1}$ can be attributed to the stretching vibration of the In-O bond. The O-H bond mainly comes from $[\mathrm{In}(\mathrm{OH})]_{(3-\mathrm{x})}{ }^{+}$, and the hydrolysis reaction of precursor is as follows [18]:

$$
\mathrm{In}^{3+}+\mathrm{xH}_{2} \mathrm{O} \rightarrow[\operatorname{In}(\mathrm{OH})]^{(3-x)+}+\mathrm{xH}^{+}
$$

where $\mathrm{x}$ is the stoichiometric number.

Excessive concentration of such functional groups easily causes adverse effects on the electrical properties of TFTs, such as high leakage current. It can be seen from Figure 3 that with the increase of annealing temperature, the vibration peak intensity of the $\mathrm{O}-\mathrm{H}$ bond decreases significantly, which is almost zero at $300^{\circ} \mathrm{C}$. Based on the discussion above, an annealing temperature higher than $250{ }^{\circ} \mathrm{C}$ is necessary for promoting metal-oxide bond formation. Combined with the process requirements of device preparation, such as preventing the defects from the hillock of the $\mathrm{Al}$ electrode, the appropriate annealing temperature range of $\operatorname{In}_{2} \mathrm{O}_{3}$ thin films is $250{ }^{\circ} \mathrm{C}$ to $300{ }^{\circ} \mathrm{C}$. 


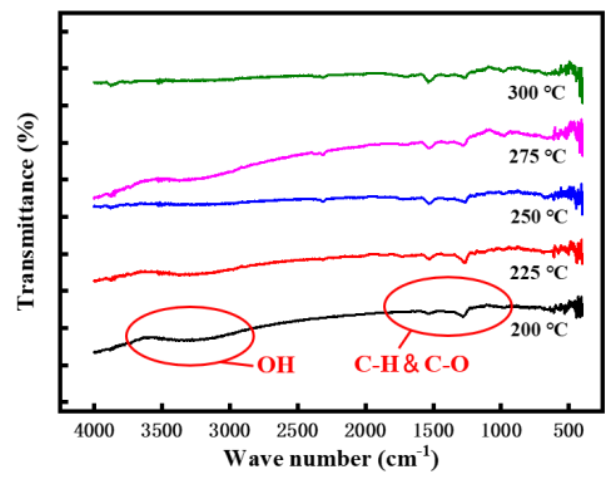

Figure 3. Fourier transform infrared (FT-IR) spectroscopy curves of $\operatorname{In}_{2} \mathrm{O}_{3}$ thin films annealed at different temperatures.

To investigate the influence of the annealing temperature on the surface morphology and thickness of $\operatorname{In}_{2} \mathrm{O}_{3}$ thin films, AFM and XRR was used. The AFM scanning area of the images was $4.0 \mu \mathrm{m} \times 4.0 \mu \mathrm{m}$. Figure $4 \mathrm{a}-\mathrm{e}$ shows AFM images of $\operatorname{In}_{2} \mathrm{O}_{3}$ thin films annealed at different temperature, and it can be seen that all samples show a relatively smooth morphology without cracks with low roughness (below $0.4 \mathrm{~nm}$ ). At the same time, the thickness of $\mathrm{In}_{2} \mathrm{O}_{3}$ films at different annealing temperatures are in the range of 3-7 nm, which indicates that they are all nano-scale films.

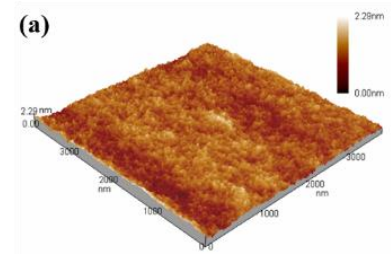

(a)

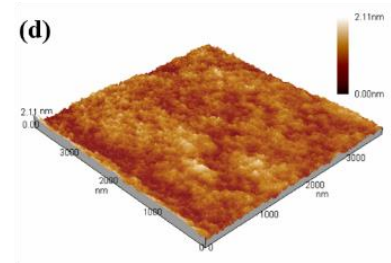

(b)

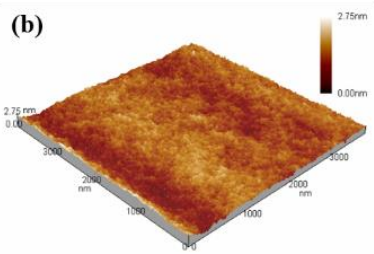

(e)

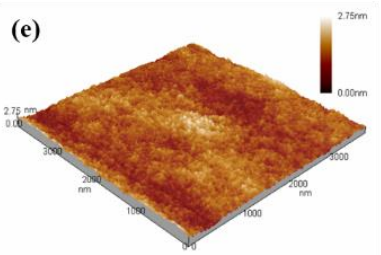

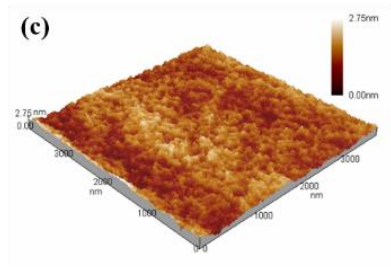

(c)

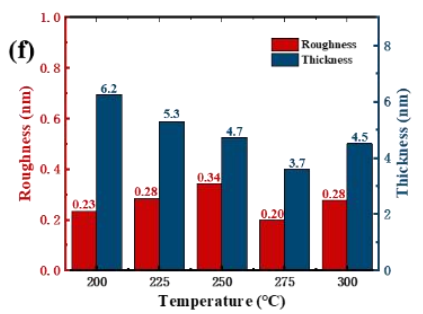

Figure 4. Atomic force microscopy (AFM) 3D images $\left(4.0 \times 4.0 \mu \mathrm{m}^{2}\right)$ of $\operatorname{In}_{2} \mathrm{O}_{3}$ thin films annealed at different temperatures: (a) $200{ }^{\circ} \mathrm{C},(\mathbf{b}) 225^{\circ} \mathrm{C}$, (c) $250^{\circ} \mathrm{C}$, (d) $275^{\circ} \mathrm{C}$, (e) $300{ }^{\circ} \mathrm{C}$, respectively. (f) The surface roughness and thickness of these films.

In our previous studies, it was found that $\operatorname{In}_{2} \mathrm{O}_{3}$ thin films crystallized only at temperatures above $400{ }^{\circ} \mathrm{C}$ [17]. Therefore, we only studied the crystallization of $\mathrm{In}_{2} \mathrm{O}_{3}$ thin films at $200-300{ }^{\circ} \mathrm{C}$ in this work. It can be seen from Figure 5 that as the annealing temperature increases, a diffraction peak related to cubic $\operatorname{In}_{2} \mathrm{O}_{3}$ gradually appears in the film around $31^{\circ}$, which indicates an increased transformation from amorphous phase into crystalline phase. According to the test results, when the temperature is $275^{\circ} \mathrm{C}$ and below, the diffraction peak has a large full width at half maxima (FWHM), weak intensity, and extremely low crystallinity, which indicates that the $\mathrm{In}_{2} \mathrm{O}_{3}$ thin films prepared by the spin coating can maintain an amorphous structure at this annealing temperature. The amorphous $\operatorname{In}_{2} \mathrm{O}_{3}$ thin films can achieve better flatness and uniformity than crystalline films, and is conducive to the control of carrier concentration [38]. 


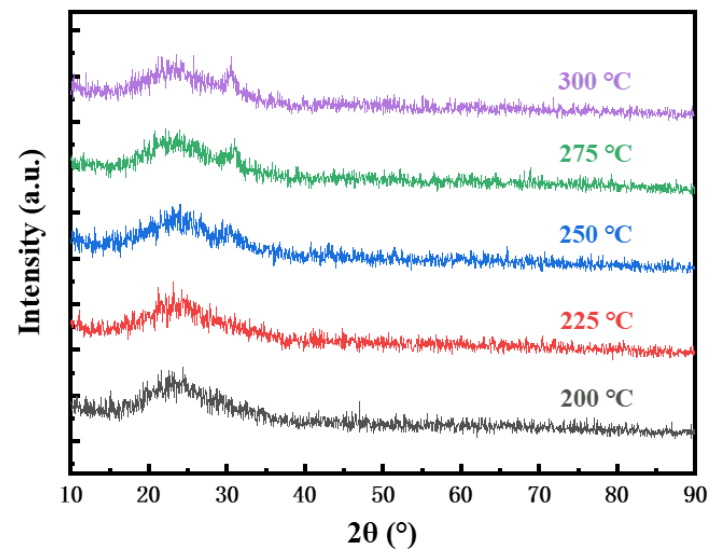

Figure 5. X-ray diffraction (XRD) curves of $\mathrm{In}_{2} \mathrm{O}_{3}$ annealed at different temperatures.

$\mathrm{In}_{2} \mathrm{O}_{3}$-TFTs were prepared under the optimized conditions. Figure 6 shows the transfer I-V characteristics of $\mathrm{In}_{2} \mathrm{O}_{3}$-TFTs at different annealing temperatures, and their corresponding electrical characteristics are listed in Table 1. It can be seen from Figure 6 that the devices had a certain negative shift and a large hysteresis, which indicated that there were many defects in the active layer. Combined with the test results in Figure 3, it may be the residual $\mathrm{OH}^{-}$in the $\mathrm{In}_{2} \mathrm{O}_{3}$ films. Another possible factor for the results is that $\mathrm{H}+$ in the $\mathrm{Si}_{3} \mathrm{~N}_{4}$ gate insulating layer. With the increase of annealing temperature, the hydroxyl group gradually decomposes, and the hysteresis phenomenon gradually weakens [39]. When the annealing temperature is $275^{\circ} \mathrm{C}$, the threshold voltage $\left(\mathrm{V}_{\text {th }}\right)$ difference between forward scanning and reverse scanning is the smallest, and the $\mathrm{In}_{2} \mathrm{O}_{3}$-TFTs showed a $\mathrm{V}_{\text {th }}$ of $0.84 \mathrm{~V}$, an $\mathrm{I}_{\text {on }} / \mathrm{I}_{\text {off }}$ ratio of $5.93 \times 10^{6}$, which was ideal.

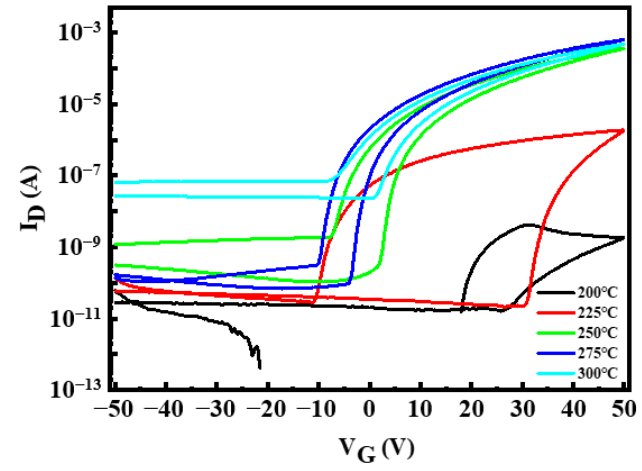

Figure 6. Transfer current-voltage (I-V) characteristics of $\operatorname{In}_{2} \mathrm{O}_{3}$-TFTs at different annealing temperature.

Table 1. Properties of $\operatorname{In}_{2} \mathrm{O}_{3}$-TFTs at different annealing temperature.

\begin{tabular}{ccccc}
\hline Temperature $\left({ }^{\circ} \mathbf{C}\right)$ & $\mathbf{V}_{\text {th }}(\mathbf{V})$ & $\mathbf{I}_{\text {on }} / \mathbf{I}_{\text {off }}$ & $\begin{array}{c}\boldsymbol{\mu}_{\text {sat }} \\
\left(\mathbf{c m}^{2} \cdot \mathbf{V}^{-\mathbf{1}} \cdot \mathbf{s}^{-\mathbf{1}}\right)\end{array}$ & SS $\left(\mathbf{V} \cdot \mathbf{d e c} \mathbf{d e c}^{-\mathbf{1})}\right.$ \\
\hline 200 & - & $2.83 \times 10^{2}$ & - & - \\
225 & 39.67 & $6.70 \times 10^{4}$ & - & - \\
250 & 6.46 & $3.00 \times 10^{5}$ & 0.837 & 1.77 \\
275 & 0.84 & $5.93 \times 10^{6}$ & 1.288 & 1.03 \\
300 & -2.93 & $7.27 \times 10^{3}$ & 1.099 & 2.69 \\
\hline
\end{tabular}

It can be seen from Table 1 that the $\mathrm{V}_{\text {th }}$ of $\operatorname{In}_{2} \mathrm{O}_{3}$-TFTs gradually negative shift with the increase of annealing temperature, which is the minimum $(0.84 \mathrm{~V})$ at $275^{\circ} \mathrm{C}$. Also, the $\mathrm{I}_{\mathrm{on}} / \mathrm{I}_{\text {off }}$ first increased to a peak value $\left(5.93 \times 10^{6}\right)$ at $275^{\circ} \mathrm{C}$, and then decreased. Furthermore, the saturation mobility $\left(\mu_{\text {sat }}\right)$ and subthreshold swing (SS) reached the maximum 
$\left(1.288 \mathrm{~cm}^{2} \cdot \mathrm{v}^{-1} \cdot \mathrm{s}^{-1}\right)$ and the minimum $\left(1.030 \mathrm{~V} \cdot \mathrm{dec}^{-1}\right)$ at $275{ }^{\circ} \mathrm{C}$ respectively. The performance is similar to that of $\operatorname{In}_{2} \mathrm{O}_{3}$-TFTs prepared by Choi at $280^{\circ} \mathrm{C}\left(\mu_{\text {sat }}\right.$ of $2.4 \mathrm{~cm}^{2} \cdot \mathrm{v}^{-1} \cdot \mathrm{s}^{-1}$, $\mathrm{I}_{\mathrm{on}} / \mathrm{I}_{\text {off }}$ of $10^{6}$ ) [40]. According to the FT-IR results, the low carrier concentration inside the $\mathrm{In}_{2} \mathrm{O}_{3}$ films at low annealing temperature may be due to the existence of undecomposed metal hydroxides in the active layer in the form of various defects, leading to the low $\mu_{\text {sat, }}$ low $\mathrm{I}_{\mathrm{on}} / \mathrm{I}_{\text {off }}$, large $\mathrm{V}_{\text {th }}$ and large SS. When the annealing temperature increased from $200{ }^{\circ} \mathrm{C}$ to $275^{\circ} \mathrm{C}$, the devices performance gradually improved. However, when the annealing temperature reached $300{ }^{\circ} \mathrm{C}$, the carrier concentration in the $\mathrm{In}_{2} \mathrm{O}_{3}$ thin films was too high, which made the device unable to turn off normally, thus, the $\mathrm{I}_{\text {on }} / \mathrm{I}_{\text {off }}$ was only $7.27 \times 10^{3}$. In addition, the continuous increase of temperature may lead to the degradation of the interface quality of the device, leading to the decrease of other performance.

\subsection{Bias Stability of Indium Oxide Thin Film Transistors $\left(\operatorname{In}_{2} \mathrm{O}_{3}\right.$-TFTs)}

Figure 7 shows the transfer curves of $\operatorname{In}_{2} \mathrm{O}_{3}$-TFTs annealed at $275{ }^{\circ} \mathrm{C}$ under positive gate bias stress (PBS) and negative gate bias stress (NBS) with a drain-bias stress of $\mathrm{V}_{\mathrm{DS}}=20 \mathrm{~V}$. During the test, a bias stress $\left(\mathrm{V}_{\mathrm{GS}}=-50 \mathrm{~V}\right.$ for NBS and $\mathrm{V}_{\mathrm{GS}}=50 \mathrm{~V}$ for PBS $)$ was applied to the gate electrode for $5400 \mathrm{~s}$. Figure 8 shows the energy band change of $\mathrm{In}_{2} \mathrm{O}_{3}$-TFTs under bias voltage. It can be seen from Figure $7 \mathrm{a}$ that the $\mathrm{V}_{\text {th }}$ under PBS drifts forward nearly $20 \mathrm{~V}$. The possible reasons are as follows: (1) the carriers were trapped by the interface defects of $\operatorname{In}_{2} \mathrm{O}_{3} / \mathrm{Si}_{3} \mathrm{~N}_{4} ;(2)$ the $\mathrm{In}_{2} \mathrm{O}_{3}$ back channel adsorbed water and oxygen in the environment, and oxygen atoms captured electrons [41]. In both cases, as shown in Figure 8a, the actual carrier concentration will be reduced, so a higher $V_{\text {th }}$ is required to form the conductive channel.
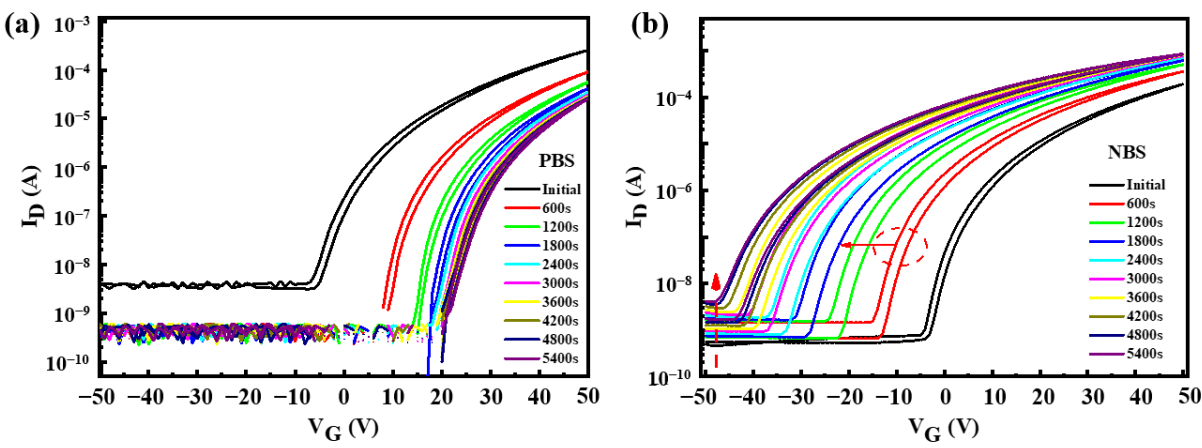

Figure 7. Transfer curves of $\mathrm{In}_{2} \mathrm{O}_{3}$-TFT annealed at $275{ }^{\circ} \mathrm{C}$ under (a) positive gate bias stress (PBS) and (b) negative gate bias stress (NBS). Measurement conditions: $\mathrm{V}_{\mathrm{DS}}=20 \mathrm{~V}$ at room temperature.

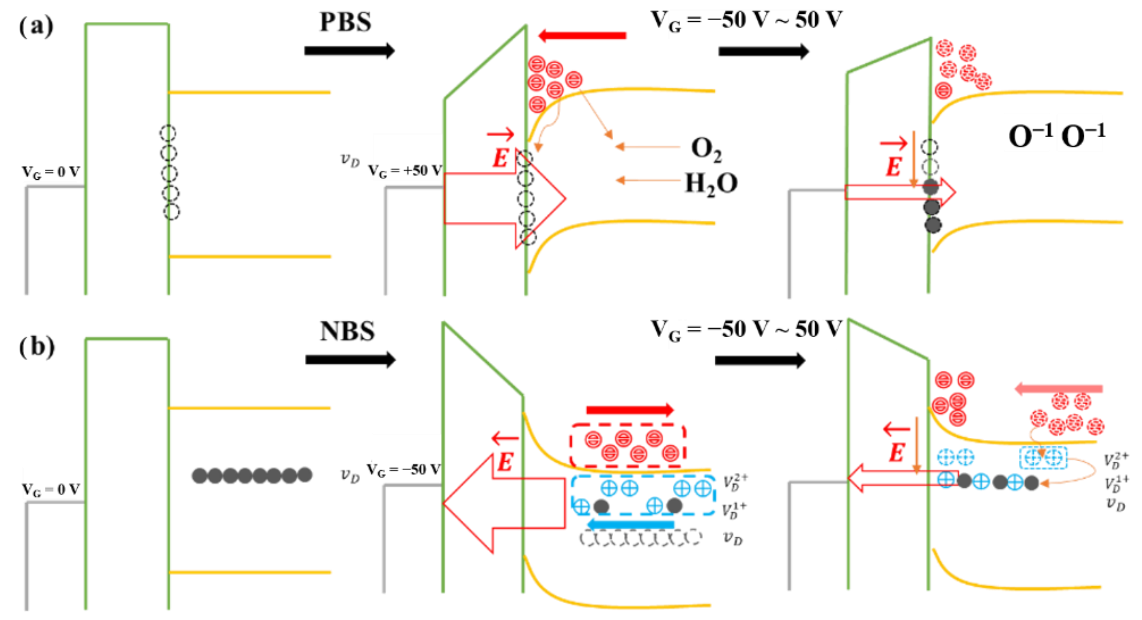

Figure 8. Plot of how about the energy band and carriers of $\mathrm{In}_{2} \mathrm{O}_{3}$-TFTs changing with the electric field under the (a) PBS and (b) NBS. 
Similarly, $\mathrm{V}_{\text {th }}$ had a drift of $-45 \mathrm{~V}$ under NBS, as shown in Figure $7 \mathrm{~b}$. In addition, with the increase of NBS time, the $\mathrm{I}_{\text {off }}$ increased and the hysteresis phenomenon became more obvious, which indicated that there were more defects in the $\operatorname{In}_{2} \mathrm{O}_{3}$ active layer, or the adsorption of water and oxygen was more serious. This was due to the activation of a large number of donors under NBS, such as impurities in the $\operatorname{In}_{2} \mathrm{O}_{3}$ films, and these electrons were removed from the active layer by the electric field. At the same time, the donors were positively charged after losing electrons, which were absorbed near the $\operatorname{In}_{2} \mathrm{O}_{3} / \mathrm{Si}_{3} \mathrm{~N}_{4}$ interface. When the bias voltage changed from $-50 \mathrm{~V}$ to $0 \mathrm{~V}$, the electric field cannot remove all the electrons generated out of the channel. Also, most of the electrons were not easy to compound with donor-like vacancies, but directly formed channel current under voltage, resulting in a negative $V_{\text {th }}$, as shown in Figure $8 b$.

\section{Conclusions}

In this study, we fabricated solution-processed $\operatorname{In}_{2} \mathrm{O}_{3}$ thin films and TFTs, and investigated the factors affecting the stability of the devices. The results show that plasma treatment can significantly improve the spreading of $\operatorname{In}_{2} \mathrm{O}_{3}$ precursor solution on the substrate surface. The $\mathrm{In}_{2} \mathrm{O}_{3}$ films without annealing contain more organic residues, and they can be significantly reduced after annealing at $275^{\circ} \mathrm{C}$ maintaining the amorphous film structure.

Through the study of the annealing characteristics of $\operatorname{In}_{2} \mathrm{O}_{3}$-TFTs, it was found that the devices prepared by the solution method have the characteristics of low active layer carrier concentration, high $\mathrm{V}_{\text {th }}$ and low $\mathrm{I}_{\mathrm{on}} / \mathrm{I}_{\text {off }}$ at low temperature. With the increase of annealing temperature, the electrical properties of the devices gradually improve. The optimal performance can be obtained after annealing at $275^{\circ} \mathrm{C}$, which exhibited a high $\mu_{\text {sat }}$ of $1.288 \mathrm{~cm}^{2} \cdot \mathrm{V}^{-1} \cdot \mathrm{s}^{-1}$, high $\mathrm{I}_{\mathrm{on}} / \mathrm{I}_{\text {off }}$ of $5.93 \times 10^{6}$, and low SS of $0.84 \mathrm{~V} \cdot \mathrm{dec}^{-1}$. Also, the bias stability is the best, which may be due to the reduction of organic residues and defects in the films. When further increasing the annealing temperature, the performance deteriorates, which may be due to the film interface degradation. This study provides a useful reference for the improvement and optimization of the performance of electronic devices prepared by the solution method.

Author Contributions: Conceptualization, R.Y. and W.X.; methodology, H.N. and W.L.; software, S.Z. and X.C.; validation, B.T. and J.W.; formal analysis, J.W. and S.Z.; investigation, X.F. and W.L.; resources, W.X.; data curation, X.C.; writing—original draft preparation, X.F.; writing-review and editing, X.F. and J.P.; visualization, R.Y.; supervision, J.P.; project administration, H.N.; funding acquisition, H.N. All authors have read and agreed to the published version of the manuscript.

Funding: This research was funded by Key-Area Research and Development Program of Guangdong Province (No.2020B010183002), National Natural Science Foundation of China (Grant No.51771074, 62074059 and 22090024), Guangdong Major Project of Basic and Applied Basic Research (No.2019B030302007), Fundamental Research Funds for the Central Universities (No. 2020ZYGXZR060 and 2019MS012), Ji Hua Laboratory scientific research project (X190221TF191), South China University of Technology 100 Step Ladder Climbing Plan Research Project (No.j2tw202004035, j2tw202004034 and j2tw202004095), National College Students' Innovation and Entrepreneurship Training Program (No.202010561001, 202010561004 and 202010561009) and 2020 Guangdong University Student Science and Technology Innovation Special Fund (“Climbing Plan” Special Fund).

Conflicts of Interest: The authors declare no conflict of interest.

\section{References}

1. Twyman, N.M.; Tetzner, K.; Anthopoulos, T.D.; Payne, D.J.; Regoutz, A. Rapid photonic curing of solution-processed $\mathrm{In}_{2} \mathrm{O}_{3}$ layers on flexible substrates. Appl. Surf. Sci. 2019, 479, 974-979. [CrossRef]

2. Chen, R.; Lan, L. Solution-processed metal-oxide thin-film transistors: A review of recent developments. Nanotechnology 2019, 30, 312001. [CrossRef]

3. Lee, S.; Shin, J.; Jang, J. Top Interface Engineering of Flexible Oxide Thin-Film Transistors by Splitting Active Layer. Adv. Funct. Mater. 2017, 27, 1604921. [CrossRef] 
4. Xu, W.; Long, M.; Zhang, T.; Liang, L.; Cao, H.; Zhu, D.; Xu, J. Fully solution-processed metal oxide thin-film transistors via a low-temperature aqueous route. Ceram. Int. 2017, 43, 6130-6137. [CrossRef]

5. Nomura, K.; Ohta, H.; Takagi, A.; Kamiya, T.; Hirano, M.; Hosono, H. Room-temperature fabrication of transparent flexible thin-film transistors using amorphous oxide semiconductors. Nat. Cell Biol. 2004, 432, 488-492. [CrossRef]

6. Park, J.S.; Maeng, W.J.; Kim, H.S.; Park, J.S. Review of recent developments in amorphous oxide semiconductor thin-film transistor devices. Thin Solid Films 2012, 520, 1679-1693. [CrossRef]

7. Myny, K. The development of flexible integrated circuits based on thin-film transistors. Nat. Electron. 2018, 1, 30-39. [CrossRef]

8. Nomura, K.; Ohta, H.; Ueda, K.; Kamiya, T.; Hirano, M.; Hosono, H. Thin-Film Transistor Fabricated in Single-Crystalline Transparent Oxide Semiconductor. Science 2003, 300, 1269-1272. [CrossRef] [PubMed]

9. Karnaushenko, D.; Münzenrieder, N.; Karnaushenko, D.D.; Koch, B.; Meyer, A.K.; Baunack, S.; Petti, L.; Tröster, G.; Makarov, D.; Schmidt, O.G. Biomimetic Microelectronics for Regenerative Neuronal Cuff Implants. Adv. Mater. 2015, 27, 6797-6805. [CrossRef] [PubMed]

10. Huang, G.; Duan, L.; Dong, G.; Zhang, D.; Qiu, Y. High-Mobility Solution-Processed Tin Oxide Thin-Film Transistors with High-k Alumina Dielectric Working in Enhancement Mode. ACS Appl. Mater. Interfaces 2014, 6, 20786-20794. [CrossRef] [PubMed]

11. Bin Esro, M.; Vourlias, G.; Somerton, C.; Milne, W.I.; Adamopoulos, G. High-Mobility ZnO Thin Film Transistors Based on Solution-processed Hafnium Oxide Gate Dielectrics. Adv. Funct. Mater. 2015, 25, 134-141. [CrossRef]

12. Cai, W.; Wilson, J.; Zhang, J.; Park, S.; Majewski, L.; Song, A. Low-Voltage, Flexible InGaZnO Thin-Film Transistors Gated with Solution-Processed, Ultra-Thin $\mathrm{Al}_{\mathrm{x}} \mathrm{O}_{\mathrm{y}}$. IEEE Electron Device Lett. 2018, 40, 36-39. [CrossRef]

13. Chen, C.-K.; Hsieh, H.-H.; Shyue, J.-J.; Wu, C.-C. The Influence of Channel Compositions on the Electrical Properties of Solution-Processed Indium-Zinc Oxide Thin-Film Transistors. J. Disp. Technol. 2009, 5, 509-514. [CrossRef]

14. Jang, J.; Kitsomboonloha, R.; Swisher, S.L.; Park, E.S.; Kang, H.; Subramanian, V. Transparent High-Performance Thin Film Transistors from Solution-Processed $\mathrm{SnO}_{2} / \mathrm{ZrO}_{2}$ Gel-like Precursors. Adv. Mater. 2012, 25, 1042-1047. [CrossRef]

15. Lee, C.-G.; Dodabalapur, A. Solution-processed zinc-tin oxide thin-film transistors with low interfacial trap density and improved performance. Appl. Phys. Lett. 2010, 96, 243501. [CrossRef]

16. Kim, S.J.; Yoon, S.; Kim, H.J. Review of solution-processed oxide thin-film transistors. Jpn. J. Appl. Phys. 2014, 53, $02 B$ A02. [CrossRef]

17. Zhang, J.; Fu, X.; Zhou, S.; Ning, H.; Wang, Y.; Guo, D.; Cai, W.; Li, J.-A.; Yao, R.; Peng, J. The Effect of Zirconium Doping on Solution-Processed Indium Oxide Thin Films Measured by a Novel Nondestructive Testing Method (Microwave Photoconductivity Decay). Coatings 2019, 9, 426. [CrossRef]

18. Park, S.; Kim, C.H.; Lee, W.J.; Sung, S.; Yoon, M.H. Sol-gel metal oxide dielectrics for all-solution-processed electronics. Mater. Eng. R Rep. 2017, 114, 1-22. [CrossRef]

19. Chang, S.B.; Chae, H.U.; Kim, H.S. Structural, optical, electrical and morphological properties of different concentration sol-gel $\mathrm{ZnO}$ seeds and consanguineous $\mathrm{ZnO}$ nanostructured growth dependence on seeds. J. Alloys Compd. 2017, 729, 571-582.

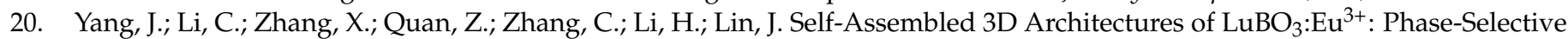
Synthesis, Growth Mechanism, and Tunable Luminescent Properties. Chemistry 2008, 14, 4336-4345. [CrossRef]

21. Rana, A.U.H.S.; Kang, M.; Kim, H.-S. Microwave-assisted Facile and Ultrafast Growth of ZnO Nanostructures and Proposition of Alternative Microwave-assisted Methods to Address Growth Stoppage. Sci. Rep. 2016, 6, 24870. [CrossRef] [PubMed]

22. Hafeezullah; Yamani, Z.H.; Iqbal, J.; Qurashi, A.; Hakeem, A.S. Rapid sonochemical synthesis of $\operatorname{In}_{2} \mathrm{O}_{3}$ nanoparticles their doping optical, electrical and hydrogen gas sensing properties. J. Alloys Compd. 2014, 616, 76-80. [CrossRef]

23. Rana, A.U.H.S.; Kim, H.S. NH4OH Treatment for an Optimum Morphological Trade-off to Hydrothermal Ga-Doped n-ZnO/p-Si Heterostructure Characteristics. Materials 2018, 11, 37. [CrossRef] [PubMed]

24. Zhang, G.; Lu, K.; Zhang, X.; Yuan, W.; Shi, M.; Ning, H.; Tao, R.; Liu, X.; Yao, R.; Peng, J. Effects of Annealing Temperature on Optical Band Gap of Sol-gel Tungsten Trioxide Films. Micromachines 2018, 9, 377. [CrossRef]

25. Zheng, M.J.; Zhang, L.D.; Li, G.H.; Zhang, X.Y.; Wang, X.F. Ordered indium-oxide nanowire arrays and their photoluminescence properties. Appl. Phys. Lett. 2001, 79, 839-841. [CrossRef]

26. Seo, S.-J.; Choi, C.G.; Hwang, Y.-H.; Bae, B.-S. High performance solution-processed amorphous zinc tin oxide thin film transistor. J. Phys. D Appl. Phys. 2008, 42, 035106. [CrossRef]

27. Chiang, H.Q.; Wager, J.; Hoffman, R.L.; Jeong, J.; Keszler, D.A. High mobility transparent thin-film transistors with amorphous zinc tin oxide channel layer. Appl. Phys. Lett. 2005, 86, 013503. [CrossRef]

28. Nguyen, M.-C.; Jang, M.; Lee, D.-H.; Bang, H.-J.; Lee, M.; Jeong, J.K.; Yang, H.; Choi, R. Li-Assisted Low-Temperature Phase Transitions in Solution-Processed Indium Oxide Films for High-Performance Thin Film Transistor. Sci. Rep. 2016, 6, 25079. [CrossRef]

29. Choi, H.S.; Cho, W.J. Controlling In-Ga-Zn-O Thin-Film Resistance by Vacuum Rapid Thermal Annealing and Application to Transparent Electrode. Phys. Status Solidi 2019, 216, 1800653.1-1800653.6. [CrossRef]

30. Nguyen, M.-C.; Nguyen, A.H.T.; Ji, H.; Cheon, J.; Kim, J.-H.; Yu, K.-M.; Cho, S.-Y.; Kim, S.-W.; Choi, R. Application of Single-Pulse Charge Pumping Method on Evaluation of Indium Gallium Zinc Oxide Thin-Film Transistors. IEEE Trans. Electron. Dev. 2018, 65, 3786-3790. [CrossRef]

31. Kim, H.S.; Byrne, P.D.; Facchetti, A.; Marks, T.J. High Performance Solution-Processed Indium Oxide Thin-Film Transistors. J. Am. Chem. Soc. 2008, 130, 12580-12581. [CrossRef] [PubMed] 
32. Troughton, J.; Atkinson, D. Amorphous InGaZnO and metal oxide semiconductor devices: An overview and current status. J. Mater. Chem. C 2019, 7, 12388-12414. [CrossRef]

33. Jeon, H.; Jin, S.Y.; Park, W.H.; Lee, H.; Kim, H.T.; Ryou, M.H.; Lee, Y.M. Plasma-assisted water-based $\mathrm{Al}_{2} \mathrm{O}_{3}$ ceramic coating for polyethylene-based microporous separators for lithium metal secondary batteries. Electrochim. Acta 2016, 212, 649-656. [CrossRef]

34. Huang, K.-M.; Ho, C.-L.; Chang, H.-J.; Wu, M.-C. Fabrication of inverted zinc oxide photonic crystal using sol-gel solution by spin coating method. Nanoscale Res. Lett. 2013, 8, 306. [CrossRef] [PubMed]

35. Zhuang, L.; Jiang, K.; Zhang, G.; Tang, J.; Lee, S.W.R. O-2 Plasma Treatment in Polymer Insulation Process for Through Silicon Vias. In Proceedings of the 2014 15th International Conference on Electronic Packaging Technology (ICEPT), Chengdu, China, 12-15 August 2014.

36. Tho, S.Y.; Ibrahim, K.; Kamarulazizi, B.I. Plasma Pre-Treatment of Polyethylene Terephthalate Substrate Influence on the Properties of ZnO Thin Film. Adv. Mater. Res. 2014, 895, 41-44. [CrossRef]

37. Park, J.H.; Yoo, Y.B.; Lee, K.H.; Jang, W.S.; Oh, J.Y.; Chae, S.S.; Lee, H.W.; Han, S.W.; Baik, H.K. Boron-Doped Peroxo-Zirconium Oxide Dielectric for High-Performance, Low-Temperature, Solution-Processed Indium Oxide Thin-Film Transistor. ACS Appl. Mater. Interfaces 2013, 5, 8067-8075. [CrossRef]

38. Park, J.H.; Kim, K.; Yoo, Y.B.; Park, S.Y.; Lim, K.-H.; Lee, K.H.; Baik, H.K.; Kim, Y.S. Water adsorption effects of nitrate ion coordinated $\mathrm{Al}_{2} \mathrm{O}_{3}$ dielectric for high performance metal-oxide thin-film transistor. J. Mater. Chem. C 2013, 1, 7166-7174. [CrossRef]

39. Jiang, S.; Zhang, Q.; Li, Y.; Zhang, Y.; Sun, X.; Jiang, B. Structural characteristics of $\mathrm{SrTiO}_{3}$ thin films processed by rapid thermal annealing. J. Cryst. Growth 2005, 274, 500-505. [CrossRef]

40. Choi, C.-H.; Han, S.-Y.; Su, Y.-W.; Fang, Z.; Lin, L.-Y.; Cheng, C.-C.; Chang, C.-H. Fabrication of high-performance, lowtemperature solution processed amorphous indium oxide thin-film transistors using a volatile nitrate precursor. J. Mater. Chem. $C$ 2014, 3, 854-860. [CrossRef]

41. Kang, D.; Lim, H.; Kim, C.; Song, I.; Park, J.; Park, Y.; Chung, J. Amorphous gallium indium zinc oxide thin film transistors: Sensitive to oxygen molecules. Appl. Phys. Lett. 2007, 90, 192101. [CrossRef] 